\title{
Productivity Testing Design Method of Multi-Factor Control for Unconsolidated Sandstone Gas Reservoir
}

\author{
Muwang Wu, Hao Liang, Mingjie Zhang, Dianqiang Sun, Peng Zhong \\ CNOOC China Ltd. Zhanjiang Branch, Zhanjiang, China \\ Email:lianghao8@cnooc.com.cn
}

How to cite this paper: $\mathrm{Wu}, \mathrm{M} . \mathrm{W}$., Liang, H., Zhang, M.J., Sun, D.Q. and Zhong, P. (2016) Productivity Testing Design Method of Multi-Factor Control for Unconsolidated Sandstone Gas Reservoir. Engineering, 8, 815822.

http://dx.doi.org/10.4236/eng.2016.811073

Received: April 8, 2016

Accepted: November 22, 2016

Published: November 25, 2016

Copyright $\odot 2016$ by authors and Scientific Research Publishing Inc. This work is licensed under the Creative Commons Attribution International License (CC BY 4.0).

http://creativecommons.org/licenses/by/4.0/

\begin{abstract}
Reservoir safety, testing-string safety, and flow control are key factors that should be considered in deep-water unconsolidated sandstone gas well testing work system. Combined with the feature of testing reservoir, pipe string type and sea area, the required minimum testing flow rate during cleaning up process, as well as minimum test flow rate without hydrate generation, pipe string erosion critical production, the maximum testing flow rate without destroying sand formation and the minimum output of meeting the demand of development was analyzed; based on the above critical test flow rates, testing working system is designed. Field application showed that the designed work system effectively provided good guidance for field test operations; no sand production or hydrate generation happened during the test process; the test parameter evaluated the reservoir accurately; the safe and efficient test operation was achieved.
\end{abstract}

\section{Keywords}

Multi-Factor Control, Productivity Testing, Unconsolidated Sandstone, Gas Well, Hydrate, Sanding

\section{Introduction}

Oil and gas well testing is the most direct means to find and learn gas and oil reservoir in the process of oil and gas exploration and development, and also provide reliable data for oil and gas field development. This needs a very accurate, reliable test data of the oil and gas layer, so as to make the scientific evaluation of oil and gas reservoirs. Oil and gas well testing technology needs to optimize the open ways of the oil and gas layer and the test technology of the working system, and ultimately achieves the scientific 
understanding of reservoir and the optimization of oil and gas well production capacity [1]. In order to ensure the success of the test, complete data and reliable interpretation, test design is needed to determine the reasonable working system of the test, although the industry has been widely paid attention to well test design, but the present well test design makes use of experience or approximate relationship to do initial estimate, lacking of a complete method to comprehensively consider the effect of various factors. Therefore, from the deep gas reservoir characteristics and testing pipe string of characteristics [2], this paper analyzed the cleaning up well critical test with liquid flow rate and critical flow rate of the formation of hydrate and the maximum test pressure difference and flow rate of sand production [3]-[10], and established the method of critical test flow to determine the reasonable work system. Field application shows good results.

\section{General Situation of the Testing Resevoir}

Well LS-X located in Lingshui sag of the east in the deep water area of Qiongdongnan Basin, is made up of several relatively independent sand body structure and lithologic trap group (divided into A, B, C, D block), as shown in Figure 1, muddy water channel sandstone reservoir developed in this tectonic area Beneath the tectonic area, the thermal fluid activity is active, petroleum entrapment conditions are good. 7 Wells in the tectonic zone are drill in I gas group of sand body, the strata thickness is between 23.8 $\mathrm{m}$ and $89.7 \mathrm{~m}$, reservoir thickness is between $11.6 \mathrm{~m}$ and $59.2 \mathrm{~m}$. In general, it is thick gray, light gray, fine sandstone and siltstone, partial grey silty mudstone in the thin layer, mudstone, single sand body that have a greater thickness. Sand body reservoir

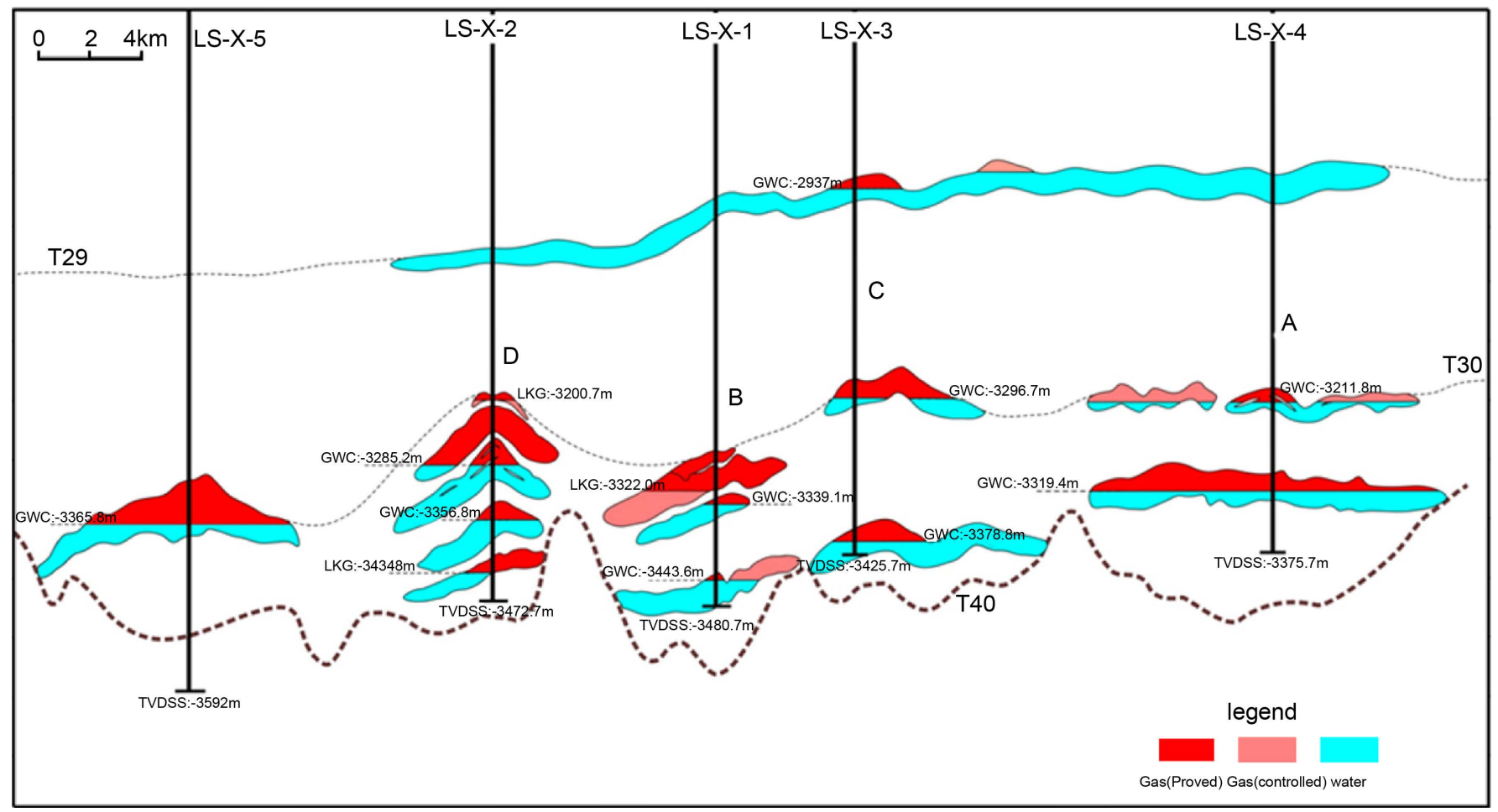

Figure 1. Lithologic traps of LS-X formation. 
only scattered in the high area of the structure from gas water distribution, having different gas water interface and the pressure system, and most are bottom water reservoir, a few are edge water gas reservoir, low water energy, the major drive type of gas reservoir is elastic drive, edge drive and bottom water drive.

Well LS-X-1 is located in the Block B of structure, all the gas horizon I, II, IV of Huangliu Formation in well LS-X-1 show good evidences of oil and gas with the depth of abnormal logging sandstone up to $64.0 \mathrm{~m}$ and the depth of logging interpretation gas horizons up to $53.4 \mathrm{~m}$. (39.1 $\mathrm{m}$ in the gas group 1, did not drill in the gas water interface) For acquisition of the reservoir parameter of physical property, deliverability and liquid in the structure LS-X-1, and providing basis for the development of the tarp group and the next step exploration, testing operation is preceded in gas horizon $\mathrm{I}_{\text {botton }}$ (3321.0 - $3351.0 \mathrm{~m}$ ) which did not drill in the gas water interface.

\section{Critical Gas Flow Rate of Well Testing}

To avoid damage on formations when testing, besides co-harmonization with different production purpose, producing method and supply and demand relations, proper testing flow should also combine with the feature of the reservoir to meet the requirements as follows: avoiding damage on down hole and reservoirs, deformation on reservoirs and mass sand production in testing wells; no gas hydrate generating when testing; testing flow with enough liquid carrying capacity.

$$
\begin{aligned}
& \max \left(Q_{\lim }, Q_{\mathrm{wc}}\right)<Q_{r}<\min \left(Q_{s}, Q_{y}\right) \\
& Q_{k}<Q_{\max }
\end{aligned}
$$

In the formula: $Q_{\lim }$ is the minimum deliverability of carrier liquid, $\mathrm{m}^{3} / \mathrm{d} ; Q_{\mathrm{wc}}$ is the minimum deliverability without hydrate, $\mathrm{m}^{3} / \mathrm{d} ; Q_{s}$ is the minimum deliverability with sand production, $\mathrm{m}^{3} / \mathrm{d} ; Q_{y}$ is the critical deliverability with reservoir deformation, $\mathrm{m}^{3} / \mathrm{d} . Q_{k}$ is the minimum output of meeting the development needs.

\subsection{The Minimum Carrying Liquid Flow Rate}

Well cleanout should be done quickly and the liquid loading (testing liquid and cush) in bore holes should be blowing off in the initial test, and the minimum air-speed needed is:

$$
v_{c}=1.912 \frac{\sigma^{0.25}\left(\rho_{L}-\rho_{g}\right)^{0.25}}{\rho_{g}^{0.5}}
$$

In the formula: $\sigma$-surface tension of blew off liquid, $\mathrm{mN} / \mathrm{m} ; \rho_{L}$-the density of down hole liquid loading, $\mathrm{kg} / \mathrm{m}^{3} ; \rho_{g}$-air density, $\mathrm{kg} / \mathrm{m}^{3}$.

Though the cross section area of test strings is $A$, the minimum flow needed to blow off the liquid loading is:

$$
q_{c}=\frac{3.06 p v_{c} A}{T Z}
$$

And the formula of surface tension is: 


$$
\begin{aligned}
& \sigma(T)=\frac{1.8 \times(137.78-T)}{206}[\sigma(23.33)-\sigma(137.78)]+\sigma(137.78) \\
& \sigma(23.33)=76 \times e^{-0.0362575 p} \\
& \sigma(137.78)=52.5-0.87018 p
\end{aligned}
$$

With the formation pressure of testing section being $39.08 \mathrm{Mpa}$, temperature being $77^{\circ} \mathrm{C}$, density of liquid loading being $1300 \mathrm{~kg} / \mathrm{m}^{3}$, relative density of gas being 0.6636 , radius of testing strings being $0.0428 \mathrm{~m}$ and gas deviation factor being 0.98 , the minimum testing flow needed by carrier liquid is computed to be $1.93 \times 10^{4} \mathrm{~m}^{3} / \mathrm{d}$.

\subsection{The Minimum Testing Flow without Hydrate Generation}

The generation of hydrate has important influence on the success of the deep high permeability gas well test, it has been lots of research about the hydrate formation scale in the deep well testing, the hydrate formation area in the test string is forecasted by using the existing model. Figure 2 shows the wellbore temperature distribution curve under different gas flow rate, it can be seen that the gas flow rate has enormous influence on the hydrate formation. When the velocity is zero (shut-in well) above $1981 \mathrm{~m}$ is hydrate stability region, the greatest supercooling appears on the mud surface, which is about $23^{\circ} \mathrm{C}$. When the velocity is $5 \times 10^{4} \mathrm{~m}^{3} / \mathrm{d}-25 \times 10^{4} \mathrm{~m}^{3} / \mathrm{d}$, the wellbore has certain hydrate stability region, and when the flow velocity is bigger than $25 \times 10^{4} \mathrm{~m}^{3} / \mathrm{d}$, hydrate can be avoided in the wellbore. Therefore, the minimum testing flow without hydrate formation is about $25 \times 10^{4} \mathrm{~m}^{3} / \mathrm{d}$.

\subsection{Maximum Testing Flow without Sand Production}

The minimum critical testing pressure difference which leads to sand production in reservoir and reservoir damage is presented as follows:

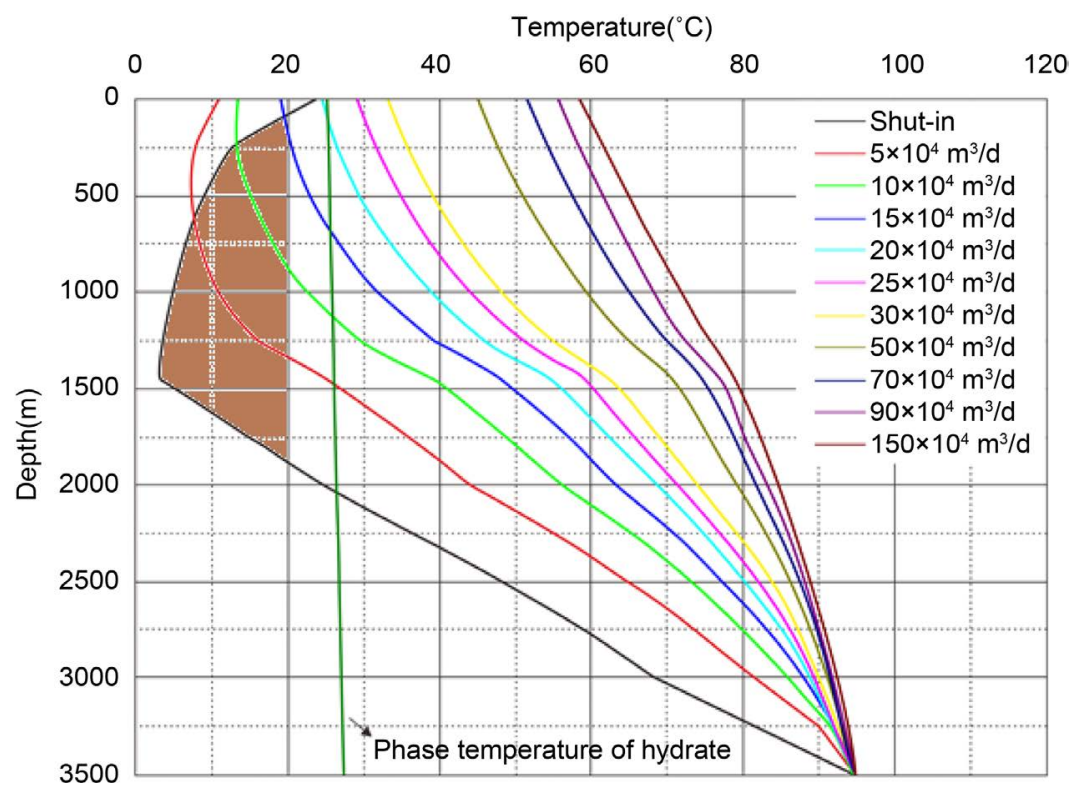

Figure 2. The wellbore temperature field under different flow rates. 


$$
\begin{gathered}
\Delta p_{s f}=C_{1} \tan \left(\frac{\pi}{4}+\frac{\phi}{2}\right) \\
\Delta p=C_{2}-\frac{2 v}{1-v}\left(10^{-6} \rho g H-P_{e}\right)
\end{gathered}
$$

In the formula: $\Delta p_{s f}$-critical pressure difference of sand production in formations, Mpa; $\Delta p$-critical pressure difference of formation damage, Mpa; $C_{1}$-rock cohesion, $\mathrm{MPa} ; \phi$-angle of internal friction; $C_{2}$-rock compressive resistance, Mpa; $v$-Poisson ratio; $\rho$-rock density, $\mathrm{g} / \mathrm{cm}^{3} ; H$-depth of reservoir, $\mathrm{m} ; P_{e}$-formation pressure, Mpa.

As showed in Figure 3, after mechanical parameters computed by logging data, the maximum pressure difference of sand production in testing section of well LS-X-1 is 1.5 $\mathrm{Mpa}$, that of formation damage is $1.96 \mathrm{Mpa}$, and numerical analogue indicates that the maximum testing flow is about $173.7 \times 10^{4} \mathrm{~m}^{3} / \mathrm{d}$ when apparent skin factor is 10 .

\subsection{The Minimum Testing Flow of the Pipe String Erosion}

Using test string in the distribution of temperature, pressure, the velocity distribution within the wellbore and the critical erosion speed can be further calculated, as shown in Figures $1-5$. In the $0.2 \mathrm{million} \cdot \mathrm{m}^{3} /$ day $-1.6 \mathrm{million} \cdot \mathrm{m}^{3} /$ day production circumstances, the wellbore flow are less than the critical erosion speed, erosion will not occur. When production reaches 2 million. $\mathrm{m}^{3} /$ day, the fluid velocity in reversing valve and pressure valve is greater than the critical speed of erosion, erosion occurs.

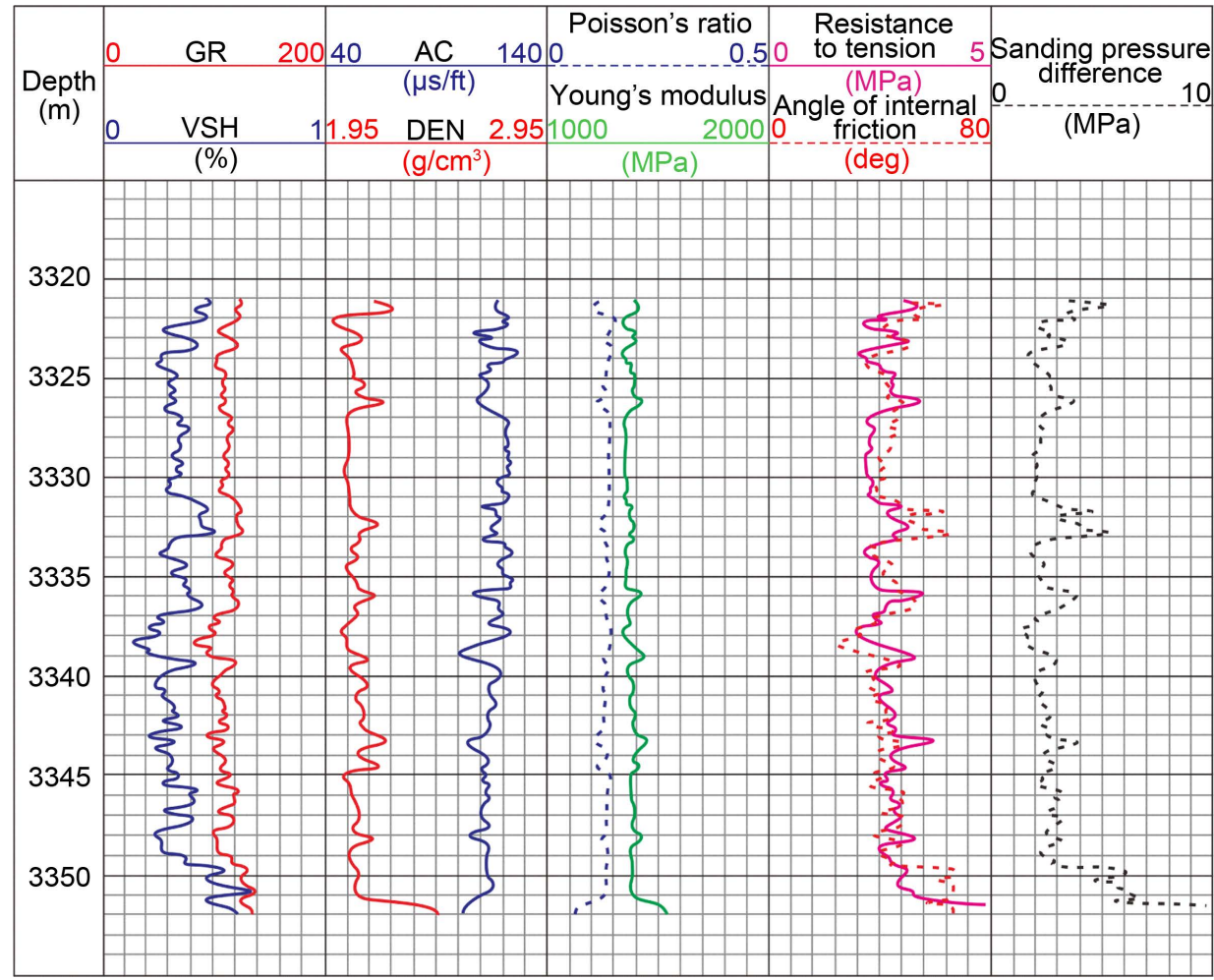

Figure 3. The critical pressure difference in test section when formation breakdown and sand production. 


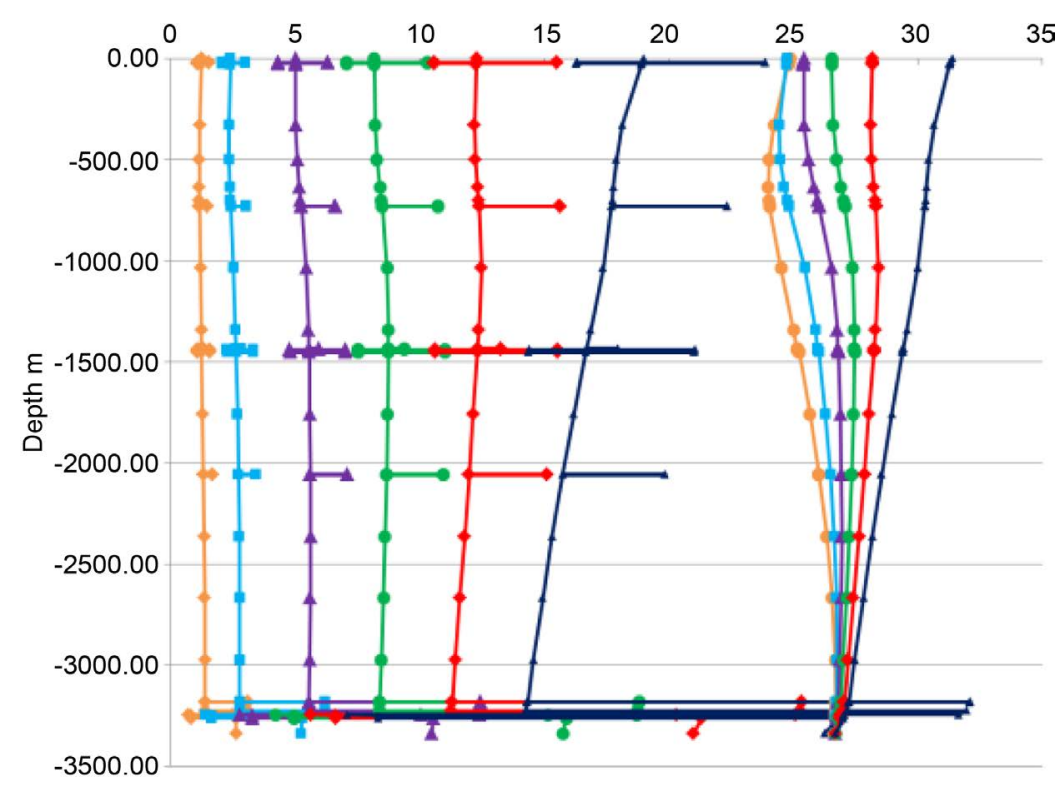

Figure 4. The wellbore flow velocity and the critical speed of erosion in LS-X-1 well.

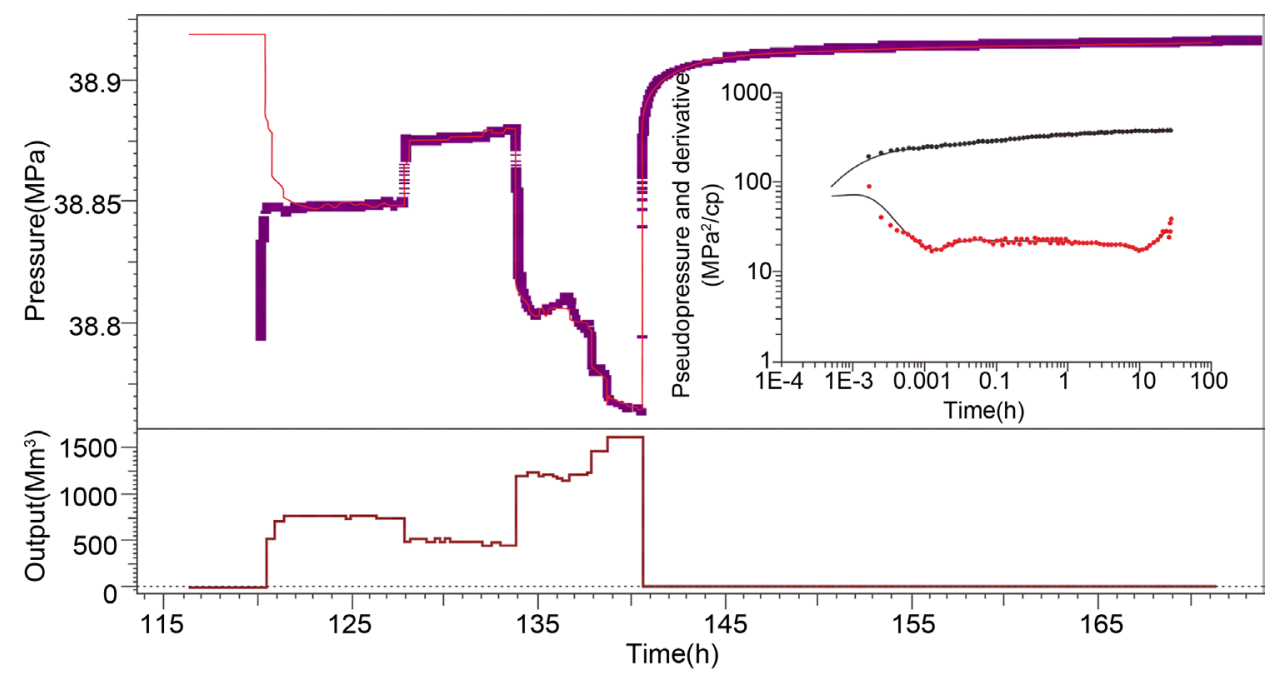

Figure 5. History matching of test pressure for LS-X-1 well.

The velocity in the small string diameter area is high when testing, and it is in the risk of eroding, in no more than testing flow of $160 \times 10^{4} \mathrm{~m}^{3} / \mathrm{d}$, there is no risk of erosion inside testing string, and safe range is larger, can satisfy the test requirement.

\subsection{The Required Production of Development}

Production of meeting the requirement of the development in the internal evaluation is $120-160 \times 10^{4} \mathrm{~m}^{3} / \mathrm{d}$.

\section{Design of Working System}

Based on the analysis, the critical testing flow is $10.75 \times 10^{4} \mathrm{~m}^{3} / \mathrm{d}$, the critical gas flow without hydrate is $25 \times 10^{4} \mathrm{~m}^{3} / \mathrm{d}$, the critical gas flow with sanding production is $162 \times$ 
Table 1. Production test program of LS-X-1 well.

\begin{tabular}{cccc}
\hline Working system & Choke size $(\mathrm{mm})$ & Gas flow $\left(10^{4} \mathrm{~m}^{3} / \mathrm{d}\right)$ & Yield time $(\mathrm{h})$ \\
\hline \multirow{3}{*}{ Initial open } & 14.29 & 70 & 10 \\
& 9.53 & 40 & 7 \\
& 19.05 & 110 & 7 \\
& 23.81 & 150 & 7 \\
\hline
\end{tabular}

$10^{4} \mathrm{~m}^{3} / \mathrm{d}$, the output that satisfies the development needs in the internal evaluation is $120-160 \times 10^{4} \mathrm{~m}^{3} / \mathrm{d}$. Thus the production testing working system is designed as is shown in Table 1.

\section{Field Application}

After reservoirs in well LS-X-1 are perforated, hydrate proofing methanol is injected into the testing system before chock manifold respectively under the mud surface, on the mud surface and above the earth surface, and the adjustable bean is opened to put through quick well cleanout, which restrains the generation of hydrate effectively. Then beans with radius of $12.70 \mathrm{~mm}, 9.53 \mathrm{~mm}, 19.05 \mathrm{~mm}$ and $25.40 \mathrm{~mm}$ are adopted to compute production, and as showed in Figure 5, the testing flows of different beans are $74.29 \times 10^{4} \mathrm{~m}^{3} / \mathrm{d}, 48.29 \times 10^{4} \mathrm{~m}^{3} / \mathrm{d}, 123.73 \times 10^{4} \mathrm{~m}^{3} / \mathrm{d}$ and $160 \times 10^{4} \mathrm{~m}^{3} / \mathrm{d}$ respectively; then after well off for $34 \mathrm{~h}$, pressure build-up test is done which is the same with the designed, the flow pressure of individual stationary point/the data of production test point have been recorded and the complete curves of build-up testing have been investigated, which constitute the complete testing data.

Data interpretation indicates that the effective permeability of gas horizon is $565 \mathrm{mD}$, total skin factor is 0.78 and wellbore storage coefficient is $0.0488 \mathrm{~m}^{3} / \mathrm{Mpa}$, combined with geological understanding, the gas and water boundary is about $1200 \mathrm{~m}$ and the lithologic boundary is about $880 \mathrm{~m}$ and $940 \mathrm{~m}$, which can clearly block out the gas range of testing reservoir.

\section{Conclusion}

Combined with the feature of pay zone and testing pipe string, the required minimum testing flow rate during cleaning up process was analyzed; afterwards temperaturepressure field model was established for testing process; minimum test flow rate required to prevent hydrate generation was calculated; and then the maximum test flow rate that before sanding was determined according to logging data; finally working system for LS-X-1 was confirmed based on those critical flow rates. Field application shows that the designed work system effectively provides good guidance for field test operations and has reached the testing purpose.

\section{References}

[1] Yin, B.T., Li, X.F., Du, H., et al. (2011) An Optimization Design for the Well Completion Test Technology. Acta Petrolei Sinica, 6, 1072-1077. 
[2] Wang, Z.F., Li, X.S., Sun, Z.P., et al. (2011) Hydrocarbon Accumulation Conditions and Exploration Potential in the Deep-Water Region, Qiongdongnan Basin. China Offshore Oil and Gas, 23, 7-13.

[3] Li, Q.P. (2006) The Situation and Challenges for Deepwater Oil and Gas Exploration and Exploitation in China. China Offshore Oil and Gas, 2, 130-133.

[4] Dai, Z., Luo, D.H., Liang, W., et al. (2012) A DST Design and Practice in Deep-Water Gas Fields, South China Sea. China Offshore Oil and Gas, 1, 25-28.

[5] Yang, S.K., Dai, Y.D., Lv, Y. and Guan, L.J. (2009) Key Techniques of Gas Well Testing in South China Sea Deep Water. China Offshore Oil and Gas, 4, 237-241.

[6] Chen, S.-M., Gong, W.X.W. and Antle, G. (2008) DST Design for Deepwater Wel with Potential Gas Hydrate Problems. OTC 19162.

[7] Chen, S.-M. (2010) Un-Planed Shut-In and Deepwater Gas Hydrate Prevention. OTC 20436.

[8] Tan, Z.J., Xiang, H., Liu, F.K. and Lv, X.C. (2006) Testing Techniques for Complex Reservoirs and Their Application in Bohai Sea. China Offshore Oil and Gas, 4, 223-228.

[9] Dick, A.J. and Marcella, L., Expro Intl. Group PLC. (2005) Deep Water Subsea Controls for Completions and Interventions. OTC 17694.

[10] Obuekwe, M.O.G.B.O. (2010) Deepwater DST Design, Planning and Operations-Offshore Niger Delta Experience. SPE 133772.

Submit or recommend next manuscript to SCIRP and we will provide best service for you:

Accepting pre-submission inquiries through Email, Facebook, LinkedIn, Twitter, etc.

A wide selection of journals (inclusive of 9 subjects, more than 200 journals)

Providing 24-hour high-quality service

User-friendly online submission system

Fair and swift peer-review system

Efficient typesetting and proofreading procedure

Display of the result of downloads and visits, as well as the number of cited articles

Maximum dissemination of your research work

Submit your manuscript at: http://papersubmission.scirp.org/

Or contact eng@scirp.org 